\title{
Difference of Procalcitonin Levels in Gram-Positive and Gram-Negative Bacterial Sepsis Patients of Indonesia Army Central Hospital Gatot Soebroto in 2016
}

\author{
Nindy Handayani $i^{1}$, Soroy Lardo ${ }^{2^{*}} \mathbb{D}$, Nunuk Nugrohowati $i^{3}$
}

${ }^{1}$ Faculty of Medicine, Universitas Pembangunan Nasional "Veteran", Jakarta, Indonesia.

${ }^{2}$ Division of Tropical Medicine and Infectious Diseases, Department of Internal Medicine, Indonesia Army Central Hospital Gatot Soebroto, Jakarta, Indonesia.

3Department of Public Health, Universitas Pembangunan Nasional "Veteran”, Jakarta, Indonesia.

\section{A B S T R A C T}

Introduction: Procalcitonin is known as a marker of infection and indicator for severity of infections. In sepsis, elevated procalcitonin levels in blood have a significant value that can be used as a sepsis biomarker. The aim of this study was to determine the mean difference of procalcitonin levels in Gram-positive and Gramnegative bacterial sepsis patients.

Methods: This study used quantitative method with cross sectional approach. The sample of this study were bacterial sepsis patients of Indonesia Army Central Hospital Gatot Soebroto in 2016 which were divided into two groups: Gram-positive and Gram-negative bacterial sepsis patients with the number of each group was 30 samples. The data were analyzed by using independent $t$ test.

Results: This study showed that mean levels of procalcitonin in Gram-positive bacterial sepsis patients was $6.47 \mathrm{ng} / \mathrm{ml}$ and Gram-negative was $66.04 \mathrm{ng} / \mathrm{ml}$. There was a significant difference between mean levels of procalcitonin in Gram-positive and Gram-negative bacterial sepsis patients of Indonesia Army Central Hospital Gatot Soebroto in 2016 with $p$ value $=0.000(p<0.05)$.

Conclusion: The mean difference of procalcitonin levels in Gram-negative bacterial sepsis patients were higher than Gram-positive bacterial sepsis patients, because Gram-negative bacteria have lipopolysaccharide which is a strong immunostimulator and increases TNF- $\alpha$ production higher than Gram-positive bacteria.

* Correspondence: soroylardo@gmail.com

JUXTA: Jurnal IImiah Mahasiswa Kedokteran Universitas Airlangga p-ISSN: 1907-3623; e-ISSN: 2684-9453

DOI: 10.20473/juxta.V13I12022.38-41

Open access under Creative Commons Attribution-ShareAlike 4.0 International License (CC-BY-SA)
ARTICLE INFO

Article history:

Received 3 September 2021

Received in revised form 17 November 2021

Accepted 28 December 2021

Available online 5 January 2022

Keywords:

Bacterial sepsis,

Gram-negative bacteria,

Gram-positive bacteria,

Infectious disease,

Procalcitonin levels. 


\section{Introduction}

Sepsis is one of the leading causes of death in the world. ${ }^{1}$ Although the understanding of patophysiology and therapy has increased, sepsis is still the cause of noncardiac death in Intensive Care Unit (ICU). The incidence of sepsis continues to rise. ${ }^{2}$ There are biomarkers of infection such as procalcitonin, C-reactive protein, and erythrocyte sedimentation rate. Among these markers, procalcitonin can show the severity of infection. ${ }^{3}$ Procalcitonin is a precursor of calcitonin. It is synthesized by $\mathrm{C}$ cells of thyroid and controlled by calcitonin gene related peptide-1 (CALC-1). The expression of CALC-1 gene is normally found in the neuroendocrine cells of thyroid and the lungs. However, during microbial infections, the release of CALC-1 gene is increased in other tissues and cells such as kidneys, liver, pancreas, leucocytes, and adipose tissue. ${ }^{4}$ Procalcitonin is also better than other biomarkers in differentiating between bacterial and nonbacterial infection. ${ }^{5}$ Procalcitonin has higher sensitivity and specificity in comparison to other inflammatory indicators such as C-reactive protein, leucocytes, and temperature. ${ }^{6}$ In sepsis, an increase procalcitonin levels in blood has a significant value, hence it can be used as biomarker of sepsis. ${ }^{5}$

Gram-positive and Gram-negative bacteria have difference in mechanism of infection. Gram-negative bacteria has endotoxin which is a stimulator of procalcitonin production. ${ }^{7}$ This study reported the difference of procalcitonin levels between Gram-positive and Gramnegative bacterial sepsis patients of Indonesia Army Central Hospital Gatot Soebroto in 2016.

\section{Methods}

This study used quantitative method with cross sectional approach. The population of this study was bacterial sepsis patients of Indonesia Army Central Hospital Gatot Soebroto which was divided into two groups, Gram-positive and Gram-negative bacterial sepsis patients with the number of each group was 30 samples. Samples of this study had the following criteria: (1) Sepis patients who were treated at Indonesia Army Central Hospital Gatot Soebroto with positive result of blood culture and (2) were measured on procalcitonin test. This study was approved by the Ethics Committee, Faculty of Medicine, Universitas Pembangunan Nasional "Veteran" Jakarta, Indonesia.

The data from medical record were collected between January - February 2018. The technique of data collection was using consecutive sampling. Independent $T$ Test was used to detect differences between two groups. $P$ value $<$ 0.05 was considered as statistically significant.

\section{Results}

\section{Patients Characteristics and Bacterial Species}

From 60 bacterial sepsis patients, $25(41.7 \%)$ men and $35(58.3 \%)$ women were included. The mean age of the patients was $53.5 \pm 16.1$ years old. The source of infections was from respiratory system $(53.3 \%)$, digestive system (13.3\%), urinary system (16.7\%), and soft tissues (16.7\%). Among these patients, there were 16 (26.7\%) patients with multiple organ dysfunction syndrome (MODS) and 44 (73.3\%) patients without MODS. The most frequent causative bacterial species from Gram-positive bacterial sepsis patients were Staphylococcus epidermidis (50\%) and Gram-negative bacterial sepsis patients were Klebsiella pneumoniae ssp pneumonia (43.3\%). (Table 1).

Table 1. Demographic and clinical data of bacterial sepsis patients

\begin{tabular}{ll}
\hline Parameter & $\begin{array}{l}\text { Bacterial } \\
\text { sepsis patients } \\
(\boldsymbol{n}=\mathbf{6 0})\end{array}$ \\
\hline Demographic characteristics & \\
Sex (male/female) & $25 / 35$ \\
Age (years old; mean \pm SD) & $53.5 \pm 16.1$ \\
\hline Infection source & \\
Respiratory system & 32 \\
Digestive system & 8 \\
Urinary system & 10 \\
Soft tissues & 10 \\
\hline Multiple organ dysfunction & \\
syndrome (MODS) & \\
With MODS & 16 \\
Without MODS & 44 \\
\hline Bacterial species & \\
Gram-positive bacteria & \\
Staphylococcus haemolyticus & 11 \\
Staphylococcus epidermidis & 15 \\
Staphylococcus lugdonensis & 1 \\
Staphylococcus hominis & 3 \\
Gram-negative bacteria & \\
Klebsiella pneumoniae & 13 \\
Klebsiella oxytoca & 2 \\
Eschericia coli & 1 \\
Pseudomonas aeuruginosa & 5 \\
Pseudomonas luteola & 1 \\
Acinobacter baumanii & \\
Stenotrophomonas maltophilia & \\
Serratia odorifera & \\
Burkholderia cepacia & \\
\hline SD: Standard Deviation & \\
\hline & \\
\hline
\end{tabular}

\section{Difference of Procalcitonin Levels in Gram-Positive and Gram-Negative Bacterial Sepsis Patients}

According to the result of independent test, the $p$ value was $0.000(p<0.05)$. It showed that there was a 
significant difference between mean levels of procalcitonin in Gram-positive and Gram-negative bacterial sepsis patients. The mean levels of procalcitonin in Gram-positive bacterial sepsis patients was $6.47 \mathrm{ng} / \mathrm{ml}$ and Gramnegative bacterial sepsis patients was $66.04 \mathrm{ng} / \mathrm{ml}$ (Table 2).

Table 2. Difference of procalcitonin levels in Gram-positive and Gram-negative bacterial sepsis patients

\begin{tabular}{lccc}
\hline & $n$ & $\begin{array}{c}\text { Mean } \pm \text { S.D } \\
(\mathrm{ng} / \mathrm{ml})\end{array}$ & $\begin{array}{c}p \\
\text { value }\end{array}$ \\
\hline Gram-positive bacteria & 30 & $6.47 \pm 5.48$ & 0.000 \\
Gram-negative bacteria & 30 & $66.04 \pm 70.22$ & \\
\hline
\end{tabular}

\section{Discussion}

From 60 patients of bacterial sepsis patients, the mean age of bacterial sepsis patients was $53.5 \pm 16.1$ years old and the most common patients were elderly patients. There are some risk factors in elderly patients in having sepsis: (1) chronic comorbid disease, (2) poor functional status, (3) malnutrition, (4) endocrine deficiency, (5) aging, (6) recurrent and long-term hospital care that lead to high risk of nosocomial infection, (7) decreased immune system, and (8) multiple drug use..$^{8}$ In elderly patients, the induce of cytokin proinflammation is not controlled well by antiinflammation mechanism. ${ }^{9}$ The number of $B$ cells and plasma cells decreases gradually with aging. ${ }^{8}$ Innate immune cells that have the ability to identify and eliminate pathogens also have decreased functions. ${ }^{10}$ Among 60 patients, the most common patients were bacterial sepsis patient without MODS. Initial assessment and management sepsis patients before entering the intensive care unit (ICU) can reduce the risk of organ failure. ${ }^{11}$

According to the result of this study, the most frequent bacterial species of Gram-positive bacteria was Staphylococcus epidermidis. It is one of the most common causative pathogen in bacteremia and sepsis, followed by Gram-negative rods from Enterobacteriaceae family. ${ }^{12,13}$ It is one of the most prevalent Gram-positive bacterial species found on the human skin and mucous membranes and a frequent nosocomial pathogen. It can form a biofilm to inhibit the host's defense mechanisms and antibiotic therapy by producing mucopolysaccharide, protein, and nucleic acids. It also has specific protease (SepA) that can degrade antimicrobial peptides (AMPs) and inhibit the activity of neutrophil in killing bacteria. ${ }^{12,14}$

The most frequent bacterial species of Gram-negative bacteria in this study was Klebsiella pneumoniae. This result is also in line with recent findings of $\mathrm{Li}$, et al. (2016) which stated that the most frequent bacterial species of Gram-negative bacteria in sepsis was Klebsiella pneumoniae. ${ }^{15}$ It has lipopolysaccharide and capsular polysaccharide which are essential for the virulence of this pathogen. Lipopolysaccharide consists of lipid A, core, and $O$ antigen which are responsible for inhibiting complemen activity. Capsular polysaccharide is involved in protection against C3, hence it will inhibit macrophage phagocytosis. ${ }^{16,17}$ Klebsiella pneumoniae use ferricsiderophore receptors from the host to activate the iron absorption system for themselves. ${ }^{18}$

This study determined the difference between mean levels of Gram-positive and Gram-negative bacterial sepsis patients. The result of this study showed that there was a significant difference between mean levels of procalcitonin in Gram-positive and Gram-negative bacterial sepsis patients with $p$ value $0.000(p<0.05)$. Mean levels of procalcitonin in Gram-negative bacterial sepsis patients was higher than Gram-positive bacterial sepsis patients. Leli, et al. suggests that procalcitonin can distinguish Gramnegative from Gram-positive and fungal bloodstream infections. According to the study of Leli, et al. (2019), procalcitonin cut-off value of $10.8 \mathrm{ng} / \mathrm{ml}$ could be helpful in predicting Gram-negative bacterial infection with a specificity of $82.5 \% .{ }^{19}$

Gram-positive and Gram-negative bacteria have difference in the structure of the cell wall. Gram-positive bacteria has three layers; it consists of plasma membrane, periplasmic space, and peptidoglycan. Most of Grampositive bacteria have teichuronic acid and teichoic acid. Gram-negative bacteria has three components outside the peptidoglycan; lipoprotein, outer membrane, and lipopolysaccharide. ${ }^{20}$

The infection begins with the proliferation of pathogen at the site of infection, then it will invade blood vessels and release various substances such as endotoxin or exotoxin. ${ }^{21}$ These various substances can also be called pathogen-associated molecular patterns (PAMPs). In sepsis, endotoxin and exotoxin play a major role. It is thought that pathogenesis of sepsis includes microbial interaction with host defense system. Lipopolysaccharide is a substance of Gram-negative bacteria that is recognized by toll-like receptors 4 (TLR4) as a ligan. Peptidoglycan and lipoteichoic acid from Gram-positive bacteria are recognized by toll-like receptors 2 (TLR2) as ligan. ${ }^{22,23}$ After the recognition, toll-like receptors bind the PAMPs in order to be recognized by macrophage, monocyte, granulocyte, natural killer cell, and dendritic cell to iniate transcription of interferon type 1 and proinflammatory cytokines such as TNF- $\alpha$, IL-1, and IL-6. ${ }^{24}$ The binding of toll-like receptors and PAMPs activates signaling cascades in order to release inflammatory cytokines and chemokines. Toll-like receptors have toll/IL-1R domain (TIR) which is responsible to initiate signaling cascades via TIR adaptors such as myeloid differentiation primary response gene 88 (MyD88), TIR-domain-containing adaptor-inducing interferon- $\beta$ (TRIF), TIR-containing adaptor protein (TIRAP), dan TRIFrelated adaptor molecule (TRAM). Adaptors are platforms which organize the downstream signaling cascades leading to a specific cellular response. ${ }^{23,25}$ Inflammatory cytokines and chemokines initiate the release of procalcitonin in blood. ${ }^{15}$ TLR2 use TIRAP and MyD88 as adaptor and TLR4 use all adaptors. It shows that lipopolysaccharide is a strong immunostimulator. ${ }^{23}$ 
Moreover, Gram-negative bacterial infections increase TNF- $\alpha$ higher than Gram-positive bacterial infections. ${ }^{14}$

\section{Conclusion}

In conclusion, there was a significant difference between mean levels of procalcitonin in Gram-positive and Gram-negative bacterial sepsis patients. The mean levels of procalcitonin in Gram-negative bacterial sepsis patients were higher than Gram-positive bacterial sepsis. In this study, the most frequent bacterial species of Gram-positive bacteria was Staphylococcus epidermidis and Gramnegative bacteria was Klebsiella pneumoniae.

\section{CONFLICT OF INTEREST}

The author stated there is no conflict of interest in this study.

\section{REFERENCES}

1. Kochanek KD, Murphy SL, Xu J, et al. Deaths: Final Data for 2014. Natl Vital Stat Rep 2016; 65: 1-12.

2. RN T, DC L, L K. Profil Penderita Sepsis di ICU RSUP Prof. Dr. R. D. Kandou Manado Periode Desember 2014 - November 2015. urnal e-Clinic (eCl) 2016; 4: 452-457.

3. Chalupa $\mathrm{P}$, Beran $\mathrm{O}$, Herwald $\mathrm{H}$, et al. Evaluation of Potential Biomarkers for the Discrimination of Bacterial and Viral Infections. Infection 2011; 39: 411-7.

4. A C, GL SS, R J, et al. Procalcitonin in Sepsis and Bacterial Infections. J Clin Sci Res 2013; 2: 216224.

5. Coriejati, M I, EH P. Bacterial Pattern and Patient's Age on Procalcitonin in Community and Hospital Acquired Pneumonia. Indones J Clin Pathol Med Lab 2015; 2: 153-157.

6. Christ-Crain M, Opal SM. Clinical Review: the Role of Biomarkers in the Diagnosis and Management of Community-acquired Pneumonia. Crit Care 2010; 14: 203.

7. Soreng K, Levy R. Procalcitonin: An Emerging Biomarker of Bacterial Sepsis. Clin Microbiol News/ 2011; 33: $171-178$

8. Nasa P, Juneja D, Singh O. Severe Sepsis and Septic Shock in the Elderly: An Overview. World J Crit Care Med 2012; 1: 23-30.

9. Opal SM, Girard TD, Ely EW. The Immunopathogenesis of Sepsis in Elderly Patients. Clin Infect Dis 2005; 15: S504-12.

10. Gaudio AR De, Rinaldi S, Chelazzi C, et al. Pathophysiology of Sepsis in the Elderly: Clinical Impact and Therapeutic Considerations. Curr Drug Targets 2009; 10: 60-70.
11. Herrán-Monge R, Muriel-Bombín A, García-García MM, et al. Epidemiology and Changes in Mortality of Sepsis After the Implementation of Surviving Sepsis Campaign Guidelines. J Intensive Care Med 2019; 34: 740-750.

12. Kleinschmidt $S$, Huygens $F$, Faoagali $J$, et al. Staphylococcus Epidermidis as a Cause of Bacteremia. Futur Microbiol 2015; 10: 1859-79.

13. Guo SY, Zhou Y, Hu QF, et al. Procalcitonin is a Marker of Gram-Negative Bacteremia in Patients with Sepsis. Am J Med Sci 2015; 349: 499-504.

14. Kordek A. Concentrations of Procalcitonin and CReactive Protein, White Blood Cell Count, and the Immature-to-Total Neutrophil Ratio in the Blood of Neonates with Nosocomial Infections: GramNegative Bacilli vs Coagulase-Negative staphylococci. Eur J Clin Microbiol Infect Dis 2011; 30: 455-7.

15. Li S, Rong H, Guo Q, et al. Serum Procalcitonin Levels Distinguish Gram-negative Bacterial Sepsis from Gram-Positive Bacterial and Fungal Sepsis. J Res Med Sci; 21. Epub ahead of print 2016. DOI: 10.4103/1735-1995.183996.

16. Hsieh P-F, Lin T-L, Yang F-L, et al. Lipopolysaccharide O1 Antigen Contributes to the Virulence in Klebsiella Pneumoniae causing Pyogenic Liver Abscess. PLoS One 2012; 7: e33155.

17. Evrard B, Balestrino D, Dosgilbert $A$, et al. Roles of Capsule and Lipopolysaccharide $O$ Antigen in Interactions of Human Monocyte-Derived Dendritic Cells and Klebsiella Pneumoniae. Infect Immun 2010; 78: 210-9.

18. VI H. The Impact of Siderophores and Iron Acquisition on Klebsiella Pneumoniae Pathogenesis. Dr Diss Univ Michigan, 2016.

19. Leli C, Ferranti M, Moretti A, et al. Procalcitonin Levels in Gram-Positive, Gram-Negative, and Fungal Bloodstream Infections. Dis Markers 2015; 2015 : 701480.

20. Brooks GF, Carroll KC, Butel JS, et al. Jawetz, Melnick \& Adelberg's Medical Microbiology. The McGrawHill Companies, 2013, pp. 26-27.

21. Suharto. Infectious Disease in Indonesia, Current and Future Solutions. Surabaya, 2011, p. 420.

22. Elson G, Dunn-Siegrist I, Daubeuf B, et al. Contribution of Toll-Like Receptors to the Innate Immune Response to Gram-Negative and Gram-Positive Bacteria. Blood 2007; 109: 1574-83.

23. Kumar S, Ingle H, Prasad DVR, et al. Recognition of Bacterial Infection by Innate Immune Sensors. Crit Rev Microbiol 2013; 39: 229-46.

24. Gotts JE, Matthay MA. Sepsis: Pathophysiology and Clinical Management. BMJ Open; 23. Epub ahead of print 2016. DOI: $10.1136 / \mathrm{bmj} .11585$.

25. Guo B, Cheng G. Modulation of the Interferon Antiviral Response by the TBK1/IKKi Adaptor Protein TANK. J Biol Chem 2007; 282: 11817-26. 